\title{
Lycopodine-Type Alkaloids from Lycopodium japonicum
}

\author{
Juan He $\cdot$ Xing-De Wu $\cdot$ Fei Liu $\cdot$ Yu-Cheng Liu $\cdot$ \\ Li-Yan Peng $\cdot$ Yu Zhao $\cdot$ Xiao Cheng $\cdot$ \\ Huai-Rong Luo $\cdot$ Qin-Shi Zhao
}

Received: 11 May 2014/ Accepted: 13 June 2014/Published online: 17 July 2014

(C) The Author(s) 2014. This article is published with open access at Springerlink.com

\begin{abstract}
Three new lycopodine-type alkaloids, $4 \alpha$-hydroxyanhydrolycodoline (1), $4 \alpha, 6 \alpha$-dihydroxyanhydrolycodoline (2), and 6-epi-8 $\beta$-acetoxylycoclavine (3), and an artifact, lycoposerramine $G$ nitrate (4), along with seventeen related known compounds, were isolated from the club moss Lycopodium japonicum Thunb. ex Murray (Lycopodiaceae). Their structures were elucidated by extensive spectroscopic methods as well as X-ray analysis. Compounds 1-4 were evaluated for their acetylcholine esterase inhibitory activity.
\end{abstract}

Keywords Lycopodium japonicum · Lycopodine-type alkaloids $\cdot 4 \alpha$-Hydroxyanhydrolycodoline · $4 \alpha, 6 \alpha$-Dihydroxyanhydrolycodoline $\cdot 6$-epi-8 $\beta$-Acetoxylycoclavine $\cdot$ Lycoposerramine G nitrate

\section{Introduction}

Lycopodium alkaloids have attracted great interests of phytochemists and synthetic chemists for a long time due to their complicated structures as well as potent biological activities [1-5]. Till now, more than 300 Lycopodium alkaloids have been obtained [6, 7], which were classified into four structural types by chemist Ayer [8], namely, lycopodine-type, lycodine-type, fawcettimine-type, and miscellaneous-type.

Lycopodium japonicum Thunb. ex Murray, abundant in Guangdong, Guangxi, Yunnan, and Guizhou provinces of China, was historically used as a traditional folk medicine for the treatment of contusion, strains, and myasthenia. Its

Electronic supplementary material The online version of this article (doi:10.1007/s13659-014-0027-1) contains supplementary material, which is available to authorized users.

J. He · X.-D. Wu · F. Liu · Y.-C. Liu · L.-Y. Peng · Y. Zhao X. Cheng $\cdot$ H.-R. Luo $\cdot$ Q.-S. Zhao $(\bowtie)$

State Key Laboratory of Phytochemistry and Plant Resources in

West China, Kunming Institute of Botany, Chinese Academy of

Sciences, Kunming 650201, China

e-mail: qinshizhao@mail.kib.ac.cn chemical constituents have been widely investigated and a large number of compounds have been isolated [9-14]. Our previous study on this plant reported a novel Lycopodium alkaloid, lycojapodine A [15, 16]. A continuous study on the same plant led to the isolation of three new lycopodinetype alkaloids, $4 \alpha$-hydroxyanhydrolycodoline (1), $4 \alpha, 6 \alpha$ dihydroxyanhydrolycodoline (2), and 6-epi-8 $\beta$-acetoxylycoclavine (3), and an artifact, lycoposerramine $G$ nitrate (4) (Fig. 1), together with seventeen related known compounds. Compounds 1-4 were tested for their acetylcholine esterase (AChE) inhibitory activity, yet no positive results were observed. Herein, we report the isolation and structural elucidation of these compounds.

\section{Results and Discussion}

The crude base extract of $L$. japonicum was separated by normal-phase silica gel, RP-18 silica gel, and Sephadex LH-20 chromatography to afford twenty-one lycopodinetype alkaloids, seventeen of which were known ones. The structures of known compounds, compared with literature data, were identified as lycopodine [17], clavolonine [17], alkaloid L-23 [17], lucidioline [18], alkaloid L-20 [18], 


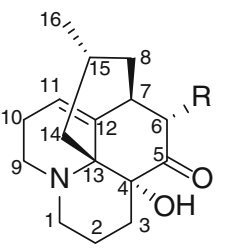

$1 \mathrm{R}=\mathrm{H} ; 2 \mathrm{R}=\mathrm{OH}$

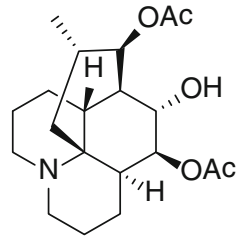

3

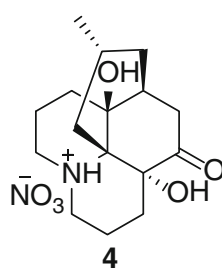

Fig. 1 Compounds 1-4 isolated from L. japonicum

lycoposerramine $\mathrm{M}$ [18], lycoposerramine $\mathrm{G}$ [18], lycoposerramine K [18], lycoposerramine F [18], anhydrolycodoline [19], lycoclavine [20], serratezomine C [21], huperzine $\mathrm{E}$ [22], 12-epilycodoline- $N$-oxide [23], diphaladine $\mathrm{A}$ [24], 12-deoxyhuperzine $\mathrm{O}$ [25], and $8 \beta$-acetoxy$11 \alpha$-hydroxylycopodine [26].

Compound $\mathbf{1}$ was obtained as a colorless crystal. Its molecular formula, $\mathrm{C}_{16} \mathrm{H}_{23} \mathrm{NO}_{2}$, was established by
HRESIMS $\left([\mathrm{M}+\mathrm{H}]^{+}\right.$at $m / z$ 262.1806). The ${ }^{1} \mathrm{H}$ NMR (Table 1) spectrum of 1 displayed one methyl $\left(\delta_{\mathrm{H}} 0.84, \mathrm{~d}\right.$, $J=6.2 \mathrm{~Hz})$ and one olefinic proton $\left(\delta_{\mathrm{H}} 5.65, \mathrm{~d}\right.$, $J=5.1 \mathrm{~Hz}$ ). The ${ }^{13} \mathrm{C}$ NMR and DEPT spectra of $\mathbf{1}$ (Table 2) exhibited 16 carbon resonances due to four quaternary carbons (one oxygenated at $\delta_{\mathrm{C}} 75.2$, one olefinic at $\delta_{\mathrm{C}} 139.9$, and one carbonyl at $\left.\delta_{\mathrm{C}} 210.5\right)$, three methines (one olefinic at $\delta_{\mathrm{C}} 118.8$ ), eight methylenes, and one methyl group at $\delta_{\mathrm{C}} 22.1$. The ${ }^{1} \mathrm{H}-{ }^{1} \mathrm{H}$ COSY and HSQC data revealed three partial structures: a $\mathrm{CH}_{2} \mathrm{CH}_{2} \mathrm{CH}_{2}$, b $\mathrm{CH}_{2} \mathrm{CH}_{2} \mathrm{CH}$, and c $\mathrm{CH}_{2} \mathrm{CHCH}_{2} \mathrm{CH}\left(\mathrm{CH}_{3}\right) \mathrm{CH}_{2}$ (Fig. 2). Further detailed 2D NMR analysis indicated compound $\mathbf{1}$ was closely related to anhydrolycodoline [19]. The only difference was that $\mathbf{1}$ possessed an $\mathrm{OH}$ additional group, which was suggested to be connected to C-4 as inferred from the HMBCs of $\delta_{\mathrm{H}} 2.25(1 \mathrm{H}, d, J=15.2 \mathrm{~Hz}, \mathrm{H}-6 \mathrm{~b})$, $1.58(1 \mathrm{H}, b r . d, J=12.1 \mathrm{~Hz}, \mathrm{H}-2 \mathrm{~b})$, and $1.25(1 \mathrm{H}, m$, $\mathrm{H}-14 \mathrm{~b})$ with C-4.

Table $1{ }^{1} \mathrm{H}$ NMR spectroscopic data for $\mathbf{1}-\mathbf{4}$ in $\mathrm{CDCl}_{3} ; J$ in $\mathrm{Hz}$ and $\delta$ in ppm

\begin{tabular}{|c|c|c|c|c|}
\hline No. & $\mathbf{1}^{\mathrm{a}}$ & $2^{\mathrm{a}}$ & $3^{\mathrm{b}}$ & $4^{\mathrm{a}}$ \\
\hline \multirow[t]{2}{*}{1} & $2.83(t, 13.2)$ & $2.83(\mathrm{~m})$ & $3.28(t d, 14.0,3.2)$ & $3.48(t d, 16.2,4.6)$ \\
\hline & $2.42^{\mathrm{c}}$ & $2.43^{\mathrm{c}}$ & $2.49(m)$ & $2.89(d d, 13.0,4.6)$ \\
\hline \multirow[t]{2}{*}{2} & $1.89(m)$ & $1.87^{\mathrm{c}}$ & $1.91(\mathrm{~m})$ & $2.22(\mathrm{~m})$ \\
\hline & $1.58($ br. $d, 12.1)$ & $1.57(\mathrm{~m})$ & $1.31(\mathrm{~m})$ & $1.49(\mathrm{~m})$ \\
\hline \multirow[t]{2}{*}{3} & $1.87(m)$ & $1.87^{\mathrm{c}}$ & $1.68^{\mathrm{c}}$ & $1.89^{\mathrm{c}}$ \\
\hline & $1.69(\mathrm{~m})$ & $1.69(\mathrm{~m})$ & $1.37(\mathrm{~m})$ & $1.89^{\mathrm{c}}$ \\
\hline 4 & & & $2.72(m)$ & \\
\hline 5 & & & $4.84(d, 6.7)$ & \\
\hline \multirow[t]{2}{*}{6} & $3.12(d d, 15.2,6.6)$ & $3.86(b r . s)$ & $3.77($ br. s) & $3.26(d d, 16.1,5.6)$ \\
\hline & $2.25(d, 15.2)$ & & & $2.19(d, 16.1)$ \\
\hline 7 & $2.76^{\mathrm{c}}$ & $2.77^{\mathrm{c}}$ & $2.33(d, 6.5))$ & $2.11(b r . d)$ \\
\hline \multirow[t]{2}{*}{8} & $1.77(d, 13.0)$ & $1.81(\mathrm{~m})$ & $4.55(d d, 11.0,5.2)$ & $1.96(m)$ \\
\hline & $1.23(\mathrm{~m})$ & $1.26(\mathrm{~m})$ & & $1.32(d d, 13.5,6.1)$ \\
\hline \multirow[t]{2}{*}{9} & $2.76^{\mathrm{c}}$ & $2.77^{\mathrm{c}}$ & $3.12(t d, 12.4,2.5)$ & $4.31(t d, 12.0,4.6)$ \\
\hline & $2.56(b r . s)$ & $2.58(d d, 10.9,6.1)$ & $2.47(\mathrm{~m})$ & $3.02^{c}$ \\
\hline \multirow[t]{2}{*}{10} & $2.42^{\mathrm{c}}$ & $2.43^{\mathrm{c}}$ & $1.68^{\mathrm{c}}$ & $2.46(m)$ \\
\hline & $1.90(\mathrm{~m})$ & $1.97(b r . d, 17.1)$ & $1.52(\mathrm{~m})$ & $1.32(\mathrm{~m})$ \\
\hline \multirow[t]{2}{*}{11} & $5.65(d, 5.1)$ & $5.79(d, 5.3)$ & $1.88(m)$ & $3.02^{\mathrm{c}}$ \\
\hline & & & $1.43(\mathrm{~m})$ & $1.47^{\mathrm{c}}$ \\
\hline 12 & & & $2.11(m)$ & \\
\hline \multirow[t]{2}{*}{14} & $2.11(d d, 12.8,3.5)$ & $2.10(d d, 12.9,4.0)$ & $2.64(d d, 13.2,6.5)$ & $1.81^{\mathrm{c}}$ \\
\hline & $1.25(\mathrm{~m})$ & $1.29(\mathrm{~m})$ & $0.97(t, 13.2)$ & $1.81^{\mathrm{c}}$ \\
\hline 15 & $1.66(m)$ & $1.52(m)$ & $2.32(m)$ & $1.47^{\mathrm{c}}$ \\
\hline 16 & $0.84(3 \mathrm{H}, d, 6.2)$ & $0.83(3 \mathrm{H}, d, 6.2)$ & $0.87(3 \mathrm{H}, d, 6.2)$ & $0.81(3 \mathrm{H}, \mathrm{d}, 6.1)$ \\
\hline OAc-5 & & & $2.04(3 \mathrm{H}, s)$ & \\
\hline OAc- 8 & & & $2.00(3 \mathrm{H}, s)$ & \\
\hline
\end{tabular}

\footnotetext{
${ }^{a}$ Measured on a Bruker DRX-500 MHz

b Measured on a Bruker AV-400 MHz

c Overlapped
} 
Table $2{ }^{13} \mathrm{C}$ NMR spectroscopic data for $\mathbf{1}-\mathbf{4}$ in $\mathrm{CDCl}_{3} ; J$ in $\mathrm{Hz}$ and $\delta$ in ppm

\begin{tabular}{|c|c|c|c|c|}
\hline No. & $1^{\mathrm{a}}$ & $2^{\mathrm{a}}$ & $\mathbf{3}^{\mathrm{b}}$ & $4^{b}$ \\
\hline 1 & $46.5 \mathrm{CH}_{2}$ & $46.3 \mathrm{CH}_{2}$ & $47.4 \mathrm{CH}_{2}$ & $46.8 \mathrm{CH}_{2}$ \\
\hline 2 & $20.0 \mathrm{CH}_{2}$ & $19.7 \mathrm{CH}_{2}$ & $19.6 \mathrm{CH}_{2}$ & $14.4 \mathrm{CH}_{2}$ \\
\hline 3 & $23.9 \mathrm{CH}_{2}$ & $23.9 \mathrm{CH}_{2}$ & $23.3 \mathrm{CH}_{2}$ & $24.3 \mathrm{CH}_{2}$ \\
\hline 4 & $75.2 \mathrm{C}$ & $77.0 \mathrm{C}$ & $27.3 \mathrm{CH}$ & $75.8 \mathrm{C}$ \\
\hline 5 & $210.5 \mathrm{C}$ & $207.3 \mathrm{C}$ & $76.4 \mathrm{CH}$ & $205.9 \mathrm{C}$ \\
\hline 6 & $43.3 \mathrm{CH}_{2}$ & $79.5 \mathrm{CH}$ & $69.2 \mathrm{CH}$ & $39.8 \mathrm{CH}_{2}$ \\
\hline 7 & $40.4 \mathrm{CH}$ & $49.3 \mathrm{CH}$ & $45.2 \mathrm{CH}$ & $38.5 \mathrm{CH}$ \\
\hline 8 & $44.0 \mathrm{CH}_{2}$ & $39.4 \mathrm{CH}_{2}$ & $79.6 \mathrm{CH}$ & $41.0 \mathrm{CH}_{2}$ \\
\hline 9 & $45.1 \mathrm{CH}_{2}$ & $45.0 \mathrm{CH}_{2}$ & $46.8 \mathrm{CH}_{2}$ & $50.3 \mathrm{CH}_{2}$ \\
\hline 10 & $25.6 \mathrm{CH}_{2}$ & $25.9 \mathrm{CH}_{2}$ & $36.4 \mathrm{CH}_{2}$ & $17.8 \mathrm{CH}_{2}$ \\
\hline 11 & $118.8 \mathrm{CH}$ & $123.2 \mathrm{CH}$ & $25.9 \mathrm{CH}_{2}$ & $29.2 \mathrm{CH}_{2}$ \\
\hline 12 & $139.9 \mathrm{C}$ & $144.6 \mathrm{C}$ & $42.6 \mathrm{CH}$ & $69.6 \mathrm{C}$ \\
\hline 13 & $63.5 \mathrm{C}$ & $64.2 \mathrm{C}$ & $54.4 \mathrm{C}$ & $65.9 \mathrm{C}$ \\
\hline 14 & $34.3 \mathrm{CH}_{2}$ & $33.7 \mathrm{CH}_{2}$ & $40.8 \mathrm{CH}_{2}$ & $35.4 \mathrm{CH}_{2}$ \\
\hline 15 & $24.7 \mathrm{CH}$ & $24.9 \mathrm{CH}$ & $29.7 \mathrm{CH}$ & $24.2 \mathrm{CH}$ \\
\hline 16 & $22.1 \mathrm{CH}_{3}$ & $22.8 \mathrm{CH}_{3}$ & $19.6 \mathrm{CH}_{3}$ & $22.1 \mathrm{CH}_{3}$ \\
\hline \multirow[t]{2}{*}{ OAc-5 } & & & $170.6 \mathrm{C}$ & \\
\hline & & & $21.1 \mathrm{CH}_{3}$ & \\
\hline \multirow[t]{2}{*}{ OAc- 8} & & & $170.6 \mathrm{C}$ & \\
\hline & & & $21.1 \mathrm{CH}_{3}$ & \\
\hline
\end{tabular}

${ }^{\text {a }}$ Measured on a Bruker DRX-500 MHz

${ }^{b}$ Measured on a Bruker AV-400 MHz
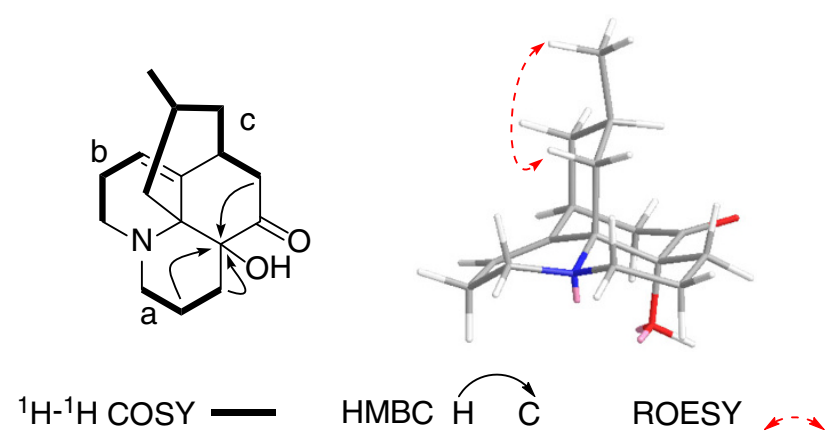

Fig. 2 Key 2D NMR correlations of compound $\mathbf{1}$

In the ROESY spectrum of $\mathbf{1}$, the correlation of $\mathrm{H}-14 \mathrm{a}$ with Me-16 was observed (Fig. 2). However, due to overlapped signals of H-1b with H-10a and H-9a with H-7, the ROESY spectrum could not provide more sufficient information to elucidate the stereochemistry of $\mathbf{1}$. The relative configuration of $\mathbf{1}$ was established by X-ray analysis (Fig. 3), which validated the $\alpha$-orientition of $\mathrm{OH}-4$, $\mathrm{H}-7$, and Me-16. Therefore, the structure of compound $\mathbf{1}$ was established as $4 \alpha$-hydroxyanhydrolycodoline.

Compound 2 was isolated a colorless crystal. The HRESIMS displayed an $[\mathrm{M}+\mathrm{H}]^{+}$peak at $\mathrm{m} / z, 278.1748$ (corresponding to a molecular formula $\mathrm{C}_{16} \mathrm{H}_{23} \mathrm{NO}_{3}$ ), 16 mass unit higher than that of $\mathbf{1}$. Comparison of the 1D NMR data (Tables 1 and 2) with those of $\mathbf{1}$, compound $\mathbf{2}$ was readily identified as 6-hydroxy derivative of $\mathbf{1}$ as deduced from the HMBCs of $\delta_{\mathrm{H}} 3.86(1 \mathrm{H}, b r . s, \mathrm{H}-6)$ with $\delta_{\mathrm{C}} 39.4(t, \mathrm{C}-8), 77.0(s, \mathrm{C}-4)$, and $207.3(s, \mathrm{C}-5)$. The relative configuration of 2 was also established by X-ray analysis, which validated the $\alpha$-orientation of $\mathrm{OH}-4, \mathrm{OH}-6$, H-7, and Me-16 (Fig. 3). Thus, the structure of 2 was elucidated as $4 \alpha, 6 \alpha$-dihydroxyanhydrolycodoline.

The molecular formula of compound $\mathbf{3}$ was determined as $\mathrm{C}_{20} \mathrm{H}_{31} \mathrm{NO}_{5}$ on the basis of its HRESIMS $\left([\mathrm{M}+\mathrm{H}]^{+}\right.$at $\mathrm{m} / \mathrm{z}$ 366.2270), indicating $6^{\circ}$ of unsaturation. IR absorption bands implied the presence of ketone $\left(1738 \mathrm{~cm}^{-1}\right)$ and $\mathrm{OH}$ $\left(3472 \mathrm{~cm}^{-1}\right.$ ) groups. The ${ }^{1} \mathrm{H}$ and ${ }^{13} \mathrm{C}$ NMR (Tables 1 and 2) spectra revealed the existence of two OAc groups, seven $s p^{3}$ methylenes, seven $s p^{3}$ methines (three oxygenated at $\delta_{\mathrm{C}}$ 69.2, 76.4, and 79.6), one $s p^{3}$ quaternary carbon, and one methyl group. The above data indicated that $\mathbf{3}$ had a similar structure to that of lycoclavine [20], except for the existence of an additional OAc group which was located at C-8 according to the HMBCs of $\delta_{\mathrm{H}} 2.11(1 \mathrm{H}, m, \mathrm{H}-12), 2.64$ $(1 \mathrm{H}, d d, J=13.2,6.5 \mathrm{~Hz}, \mathrm{H}-14 \mathrm{a})$, and $0.87(3 \mathrm{H}, d$, $J=6.2 \mathrm{~Hz}, \mathrm{Me}-16)$ with $\delta_{\mathrm{C}} 79.6(d, \mathrm{C}-8)$ as well as $\delta_{\mathrm{H}}$ $4.55(1 \mathrm{H}, d d, J=11.0,5.2 \mathrm{~Hz}, \mathrm{H}-8)$ with $\delta_{\mathrm{C}} 170.6$. To establish the relative configuration, an X-ray experiment was evolved, which suggested the relative configuration of $\mathrm{H}-4, \mathrm{H}-5, \mathrm{H}-6, \mathrm{H}-8, \mathrm{H}-12$, and $\mathrm{H}-15$ to be $\alpha, \alpha, \beta, \alpha, \beta$, and $\beta$, respectively (Fig. 4). Thus, the structure of compound 3 was elucidated and named as 6-epi-8 $\beta$-acetoxylycoclavine.

Compound 4 had a molecular formula of $\mathrm{C}_{16} \mathrm{H}_{25} \mathrm{NO}_{3}$, the same as that of lycoposerramine G [18], a known compound also isolated this time. The NMR data and detailed 2D analysis indicated the two compounds had the same planar structure. However, according to the ROESY spectrum, the two compounds also possessed the same relative configuration which indicated $\mathbf{4}$ should be a salt form of lycoposerramine G. Therefore, a X-ray experiment was implemented that confirmed $\mathbf{4}$ was lycoposerramine $\mathrm{G}$ nitrate (Fig. 4), which was produced during the isolation as verified by the TLC $\left(\mathrm{Al}_{2} \mathrm{O}_{3}\right)$.

The compounds 1-4 were tested for acetylcholine esterase (AChE) inhibitory activity, yet no positive results were observed.

\section{Experimental Section}

\subsection{General Experimental Procedures}

Melting points were obtained on an WRX-4 micro melting point apparatus (Shanghai Yice Instrument Co., Ltd., Shanghai, China). Optical rotations were measured with 


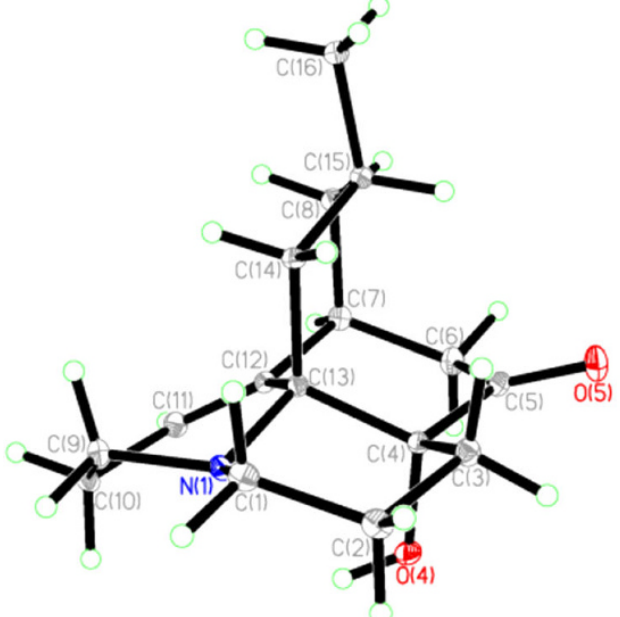

1

Fig. 3 The X-ray structures of compounds 1-2

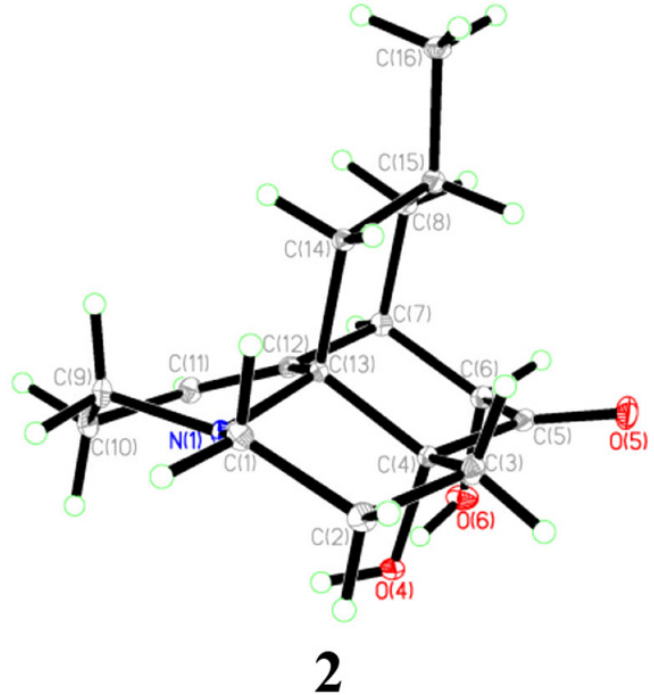

Fig. 4 The X-ray structures of compounds 3 and 4

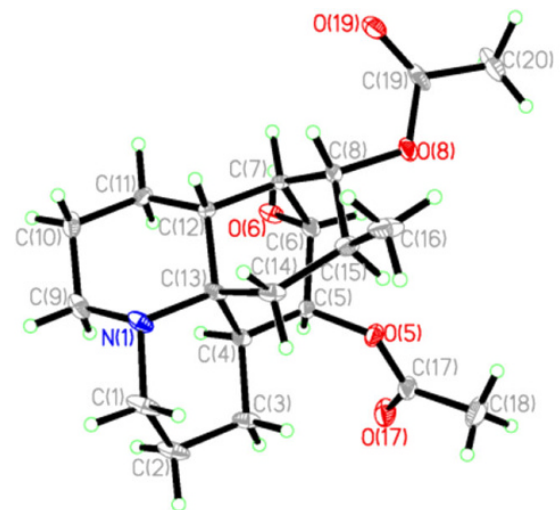

3

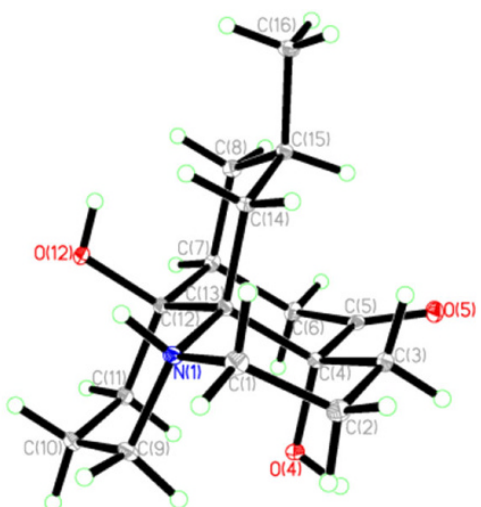

4
JASCO P-1020 digital polarimeter (JASCO, Tokyo, Japan). UV spectra were obtained using a Shimadzu UV2401A spectrophotometer (Shimadzu, Kyoto, Japan). A Tenor-27 FT infrared spectrophotometer (Bruker Optics, Ettlingen, Germany) was used for scanning IR spectrum using $\mathrm{KBr}$ pellets. ESIMS were recorded on an Agilent 6530 Q-Tof spectrometer (Agilent, Palo Alto, CA, USA). HREIMS were measured using a Waters Auto Premier P776 spectrometer (Waters, Milford, MA, USA). 1D and 2D spectra were run on Bruker AV-400 and DRX-500 spectrometers (Bruker Optics, Ettlingen, Germany). Chemical shifts $(\delta)$ were expressed in ppm with reference to the solvent signals. Column chromatography (CC) was performed on Silica gel (200-300 mesh, Qingdao Marine Chemical Ltd., Qingdao, China), RP-18 gel (20-45 $\mu \mathrm{m}$, Fuji Silysia Chemical Ltd., Japan), and Sephadex LH-20 (GE healthcare Bio-sciences AB, Sala, Sweden).
Semipreparative HPLC was performed on an Agilent 1100 liquid chromatograph (Agilent, Palo Alto, CA, USA). Liquid chromatograph was equipped with a UV detector $(190-400 \mathrm{~nm})$ and a Zorbax SB-C $18(9.4 \mathrm{~mm} \times 25 \mathrm{~cm}$ column, particle size $5 \mu \mathrm{m}, 1-3 \mathrm{~mL} / \mathrm{min})$. Fractions were monitored by Thin-layer chromatography (TLC) ( $\mathrm{GF}_{254}$, Qingdao Haiyang Chemical Co. Ltd., Qingdao, China), and spots were visualized by heating silica gel plates sprayed with $10 \% \mathrm{H}_{2} \mathrm{SO}_{4}$ in EtOH or by Dragendorff's reagent.

\subsection{Plant Material}

The whole plants of L. japonicum were collected in Simao of Yunnan Province, People's Republic of China, in August 2006. The sample was identified by Prof. Xiao Cheng at Kunming Institute of Botany, Chinese Academy of Sciences (vocher no. 2006-8-17). 


\subsection{Extraction and Isolation}

Air-dried, powdered sample $(50 \mathrm{~kg})$ of $L$. japonicum was dealt as the method reported before to obtain an base extract $(67 \mathrm{~g})$ [15]. This extract was subjected to a silica gel column chromatography (CC) with a gradient elution system of petroleum ether-actone $(1: 0-0: 1)$ to give 7 fractions (I-VI). Fraction I ( $\mathrm{g}$ ) was chromatographed over several silica gel $\mathrm{CC}$ eluted with petroleum etherEtOAc (9:1-1:1) to give three sub-fractions, I-a, I-b, and I-c. I-b was purified by $\left(\mathrm{CHCl}_{3}-\mathrm{MeOH}, 1: 1\right)$ to yield 1 $(8 \mathrm{mg}), 12$-deoxyhuperzine $\mathrm{O}(14 \mathrm{mg})$, and huperzine $\mathrm{E}$ $(7 \mathrm{mg})$. I-c was repeatedly purified by silica gel CC (petroleum ether-acetone) to afford anhydrolycodoline $(40 \mathrm{mg})$ and lycoposerramine $\mathrm{K}(27 \mathrm{mg})$. Faction II (14 g) was eluted by silica gel CC (petroleum ether-acetone) to afford four sub-fractions, II-a, II-b, II-c, and II-d. II-a repeatedly purified by silica gel CC (petroleum etheracetone, 8:2) to obtained $2(7 \mathrm{mg})$ and lycopodine (14 $\mathrm{mg})$. Alkaloid L-20 was obtained from II-b by recrystallisation. After repeatedly purified by silica gel $\mathrm{CC}\left(\mathrm{CHCl}_{3}\right.$-acetone $)$ and Sephadex $\mathrm{LH}-20\left(\mathrm{CHCl}_{3}-\mathrm{MeOH}, 1: 1\right)$, II-c give compound clavolonine $(11 \mathrm{mg})$. Faction III $(6 \mathrm{~g})$ was purified by silica gel $\mathrm{CC}\left(\mathrm{CHCl}_{3}-\mathrm{MeOH}, 9.8: 0.2\right)$, Sephadex $\mathrm{LH}-20 \mathrm{CC}\left(\mathrm{CHCl}_{3}-\mathrm{MeOH}, 1: 1\right)$, and semipreparative HPLC (MeOH- $\left.\mathrm{H}_{2} \mathrm{O}, 85: 15\right)$ to afford $3(10 \mathrm{mg})$ and $8 \beta-$ acetoxy-11 $\alpha$-hydroxylycopodine ( $3 \mathrm{mg}$ ). Fraction IV (9 g) was subjected to silica gel $\mathrm{CC}\left(\mathrm{CHCl}_{3}-\mathrm{MeOH}, 9.5: 0.5\right)$ to give three sub-fractions: IV-a, IV-b, and IV-c. Fraction IVa was purified by recrystallization and silica gel CC $\left(\mathrm{CHCl}_{3}-\mathrm{MeOH}, 9.8: 0.2\right)$ to afford lycoposerramine $\mathrm{M}$ $(16 \mathrm{mg})$, lycoclavine $(5 \mathrm{mg})$, and 12-epilycodoline- $\mathrm{N}$ oxide $(11 \mathrm{mg})$. IV-b was subjected to silica gel CC $\left(\mathrm{CHCl}_{3}-\mathrm{MeOH}, 9: 1\right)$ to yield alkaloid L-23 $(21 \mathrm{mg})$ and lycodoline $(54 \mathrm{mg})$. Fraction IV-c was subjected to silica gel $\mathrm{CC}\left(\mathrm{CHCl}_{3}-\mathrm{MeOH}, 9.5: 0.5\right)$ and then purified by recrystallization to afford $4(9 \mathrm{mg})$ and serratezomine $\mathrm{C}$ $(8 \mathrm{mg})$. Fraction-V $(11 \mathrm{~g})$ was subjected to silica gel CC $\left(\mathrm{CHCl}_{3}-\mathrm{MeOH}, 9: 1\right)$ and further purified by RP-18 CC $\left(\mathrm{MeOH}-\mathrm{H}_{2} \mathrm{O}, 4: 6-7: 3\right)$ to yield lucidioline (25 mg), lycoposerramine $\mathrm{G}(11 \mathrm{mg})$, and lycoposerramine $\mathrm{F}(10 \mathrm{mg})$. Fraction-VI ( $8 \mathrm{~g})$ was purified by $\mathrm{RP}-18 \mathrm{CC}\left(\mathrm{MeOH}-\mathrm{H}_{2} \mathrm{O}\right.$, 5:5) to afford diphaladine A (13 mg).

\subsection{Acetylcholinesterase Inhibition}

Acetylcholinesterase (AChE) inhibitory activity of the compounds 1-4 isolated was assayed by the spectrophotometric method developed by Ellman et al. [27] with slightly modification. $S$-Acetylthiocholine iodide, $S$-butyrylthiocholine iodide, 5,5'-dithio-bis-(2-nitrobenzoic) acid
(DTNB, Ellman's reagent), acetylcholinesterase derived from human erythrocytes were purchased from Sigma Chemical. Compounds were dissolved in DMSO. The reaction mixture (totally $200 \mu \mathrm{L}$ ) containing phosphate buffer ( $\mathrm{pH} 8.0)$, test compound $(50 \mu \mathrm{M})$, and acetyl cholinesterase $(0.02 \mathrm{U} / \mathrm{mL})$, was incubated for $20 \min \left(30^{\circ} \mathrm{C}\right)$. Then, the reaction was initiated by the addition of $40 \mu \mathrm{L}$ of solution containing DTNB $(0.625 \mathrm{mM})$ and acetylthiocholine iodide $(0.625 \mathrm{mM})$ for AChE inhibitory activity assay, respectively. The hydrolysis of acetylthiocholine was monitored at $405 \mathrm{~nm}$ every $30 \mathrm{~s}$ for $1 \mathrm{~h}$. Tacrine was used as positive control with final concentration of $0.333 \mu \mathrm{M}$. All the reactions were performed in triplicate. The percentage inhibition was calculated as follows: \% inhibition $=(\mathrm{E}-\mathrm{S}) / \mathrm{E} \times 100(\mathrm{E}$ is the activity of the enzyme without test compound and $\mathrm{S}$ is the activity of enzyme with test compounds).

\section{$3.54 \alpha$-Hydroxyanhydrolycodoline (1)}

Colorless crystal $(\mathrm{MeOH}) ; \quad \mathrm{mp} \quad 129-130{ }^{\circ} \mathrm{C} ; \quad[\alpha]_{\mathrm{D}}^{26}-$ $163.50\left(c 0.01, \mathrm{CHCl}_{3}\right)$; UV $(\mathrm{MeOH}) \lambda_{\max }(\log \varepsilon) 202$ (2.85) nm; IR (KBr) $v_{\max } 3362,2919,1711 \mathrm{~cm}^{-1} ;{ }^{1} \mathrm{H}$ and ${ }^{13} \mathrm{C}$ NMR data, see Tables 1 and 2; positive HRESIMS $\mathrm{m} / \mathrm{z}$ 262.1806 (calcd for $\mathrm{C}_{16} \mathrm{H}_{24} \mathrm{NO}_{2}[\mathrm{M}+\mathrm{H}]^{+}$, 262.1807).

3.6 Crystal Data for $4 \alpha$-Hydroxyanhydrolycodoline (1)

$\mathrm{C}_{16} \mathrm{H}_{23} \mathrm{NO}_{2}, \quad M=261.35 ;$ orthorhomic, space group $P 2{ }_{1} 2{ }_{1} 2_{1} ; a=7.4471$ (7) $\AA$, $b=9.7363$ (9) $\AA, c=9.2184$ (9) $\AA, \alpha=90.00, \beta=90.6970, \gamma=90.00, V=668.35$ (11) $\AA^{3}, Z=2, \mu(\mathrm{MoK} \alpha)=0.085 \mathrm{~mm}^{-1}$, crystal dimensions $0.14 \times 0.23 \times 0.45 \mathrm{~mm}$ was used for measurement on a Bruker APEX DUO diffractometer using graphitemonochromated MoK $\alpha$ radiation. The total number of reflections measured was 7187 , of which 3461 , were observed, $I>2 \sigma(I)$. Final indices: $R_{1}=0.0326$, $\mathrm{w} R_{2}=0.0912$. Crystallographic data for the structure of $\mathbf{1}$ have been deposited in the Cambridge Crystallographic Data Centre (deposition number CCDC 870095). Copies of the data can be obtained free of charge from the CCDC via www.ccdc.cam.ac.uk.

\section{$3.74 \alpha, 6 \alpha$-Dihydroxyanhydrolycodoline (2)}

Colorless crystal $(\mathrm{MeOH}) ; \quad \mathrm{mp} \quad 157-158{ }^{\circ} \mathrm{C}$; $[\alpha]_{\mathrm{D}}^{26}-91.27\left(c 0.01, \mathrm{CHCl}_{3}\right) ; \mathrm{UV}(\mathrm{MeOH}) \lambda_{\max }(\log \varepsilon)$ 203 (3.05), 264 (3.09) nm; IR (KBr) $v_{\max } 3463,3431,2921$, $1722 \mathrm{~cm}^{-1}$; ${ }^{1} \mathrm{H}$ and ${ }^{13} \mathrm{C}$ NMR data, see Tables 1 and 2; positive HRESIMS $\mathrm{m} / \mathrm{z} 278.1748$ (calcd for $\mathrm{C}_{16} \mathrm{H}_{24} \mathrm{NO}_{3}$ $\left.[\mathrm{M}+\mathrm{H}]^{+}, 278.1756\right)$. 
3.8 Crystal Data for $4 \alpha, 6 \alpha-$

Dihydroxyanhydrolycodoline (2)

$\mathrm{C}_{16} \mathrm{H}_{23} \mathrm{NO}_{3}, \quad M=277.35 ;$ orthorhomic, space group $P 2{ }_{1} 2_{1} 2_{1} ; a=7.7550 \quad(8) \AA, \quad b=8.8037 \quad$ (9) $\AA, c=$ 10.1722 (9) $\AA, \alpha=90.00, \quad \beta=98.2380, \quad \gamma=90.00$, $V=687.32$ (12) $\AA^{3}, Z=2, \mu(\operatorname{MoK} \alpha)=0.092 \mathrm{~mm}^{-1}$, crystal dimensions $0.33 \times 0.40 \times 0.40 \mathrm{~mm}$ was used for measurement on a Bruker APEX APEX DUO diffractometer using graphitemonochromated $\mathrm{MoK} \alpha$ radiation. The total number of reflections measured was 7457 , of which 3525 , were observed, $I>2 \sigma(I)$. Final indices: $R_{1}=$ $0.0335, \mathrm{w} R_{2}=0.0865$. Crystallographic data for the structure of $\mathbf{2}$ have been deposited in the Cambridge Crystallographic Data Centre (deposition number CCDC 870093). Copies of the data can be obtained free of charge from the CCDC via www.ccdc.cam.ac.uk.

\subsection{6-epi-8 $\beta$-Acetoxylycoclavine (3)}

Colorless crystal $(\mathrm{MeOH}) ; \mathrm{mp} 170-171^{\circ} \mathrm{C} ;[\alpha]_{\mathrm{D}}^{26}+40.63$ (c 0.01, $\mathrm{CHCl}_{3}$ ); UV (MeOH) $\lambda_{\max }(\log \varepsilon) 203(2.89) \mathrm{nm}$; IR (KBr) $v_{\max } 3472,2937,1738,1236,1030 \mathrm{~cm}^{-1} ;{ }^{1} \mathrm{H}$ and ${ }^{13} \mathrm{C}$ NMR data, see Tables 1 and 2; positive HRESIMS $\mathrm{m} / z$ 366.2270 (calcd for $\mathrm{C}_{20} \mathrm{H}_{32} \mathrm{NO}_{5}[\mathrm{M}+\mathrm{H}]^{+}, 366.2280$ ).

\subsection{Crystal Data for 6-epi-8 $\beta$-acetoxylycoclavine (3)}

$\mathrm{C}_{20} \mathrm{H}_{33} \mathrm{NO}_{6}\left(\mathrm{C}_{20} \mathrm{H}_{31} \mathrm{NO}_{5}+\mathrm{H}_{2} \mathrm{O}\right), \quad M=383.47$; orthorhomic, space group $P 2{ }_{1} 2{ }_{1} 2_{1} ; a=9.364$ (3) $\AA, b=12.755$ (4) $\AA, c=9.528$ (3) $\AA, \alpha=90.00, \beta=119.105, \gamma=90.00$, $V=994.3(5) \AA^{3}, Z=2, \mu(\operatorname{MoK} \alpha)=0.094 \mathrm{~mm}^{-1}$, crystal dimensions $0.05 \times 0.05 \times 0.60 \mathrm{~mm}$ was used for measurement on a Bruker APEX APEX DUO diffractometer using graphitemonochromated $\mathrm{MoK} \alpha$ radiation. The total number of reflections measured was 13705 , of which 3167 , were observed, $I>2 \sigma(I)$. Final indices: $R_{1}=0.0580$, $\mathrm{w} R_{2}=0.1206$. Crystallographic data for the structure of $\mathbf{3}$ have been deposited in the Cambridge Crystallographic Data Centre (deposition number CCDC 970097). Copies of the data can be obtained free of charge from the CCDC via www. ccdc.cam.ac.uk.

\subsection{Lycoposerramine G Nitrate (4)}

Colorless crystal $(\mathrm{MeOH}) ;[\alpha]_{\mathrm{D}}^{26}-47.21\left(c 0.01, \mathrm{CHCl}_{3}\right)$; $\mathrm{UV}(\mathrm{MeOH}) \lambda_{\max }(\log \varepsilon) 202(1.93) \mathrm{nm}$; IR (KBr) $v_{\max }$ 3421, 2924, 1720, $1439 \mathrm{~cm}^{-1} ;{ }^{1} \mathrm{H}$ and ${ }^{13} \mathrm{C}$ NMR see Tables 1 and 2; positive HRESIMS $\mathrm{m} / \mathrm{z}, 280.1913$ (calcd for $\mathrm{C}_{16} \mathrm{H}_{26} \mathrm{NO}_{3}[\mathrm{M}+\mathrm{H}]^{+}$, 280.1912).
3.12 Crystal Data for Lycoposerramine G Nitrate (4)

$\mathrm{C}_{16} \mathrm{H}_{28} \mathrm{~N}_{2} \mathrm{O}_{7}\left(\mathrm{C}_{16} \mathrm{H}_{26} \mathrm{NO}_{3}{ }^{+}+\mathrm{NO}_{3}^{-}+\mathrm{H}_{2} \mathrm{O}\right), M=360.40$; orthorhomic, space group $P 22_{1} 2_{1} 2_{1} ; a=8.5470$ (8) $\AA$, $b=8.8731$ (8) $\AA$, $c=21.963$ (2) $\mathrm{A}, \alpha=90.00, \beta=90.00$, $\gamma=90.00, \quad V=1665.6 \quad$ (3) $\AA^{3}, \quad Z=4, \quad \mu(\mathrm{MoK} \alpha)=$ $0.112 \mathrm{~mm}^{-1}$, crystal dimensions $0.30 \times 0.33 \times 0.90 \mathrm{~mm}$ was used for measurement on a Bruker APEX APEX DUO diffractometer using graphitemonochromated MoK $\alpha$ radiation. The total number of reflections measured was 17689 , of which 4580, were observed, $I>2 \sigma(I)$. Final indices: $R_{1}=0.0277, \mathrm{w} R_{2}=0.0756$. Crystallographic data for the structure of $\mathbf{4}$ have been deposited in the Cambridge Crystallographic Data Centre (deposition number CCDC 1001519). Copies of the data can be obtained free of charge from the CCDC via www.ccdc.cam.ac.uk.

\subsection{Crystal Data for Lycoposerramine G}

$\mathrm{C}_{32} \mathrm{H}_{50} \mathrm{~N}_{2} \mathrm{O}_{6}\left(2 \times \mathrm{C}_{16} \mathrm{H}_{25} \mathrm{NO}_{3}\right), M=558.74$; orthorhomic, space group $P 2{ }_{1} 2{ }_{1} 2_{1} ; a=8.2885$ (7) $\AA, b=15.8779$ (13) $\AA, c=21.1225$ (17) $\AA, \alpha=90.00, \beta=90.00, \gamma=90.00$, $V=2813.3$ (4) $\AA^{3}, \quad Z=4, \mu(\mathrm{MoK} \alpha)=0.090 \mathrm{~mm}^{-1}$, crystal dimensions $0.29 \times 0.43 \times 0.43 \mathrm{~mm}$ was used for measurement on a Bruker APEX APEX DUO diffractometer using graphitemonochromated MoK $\alpha$ radiation. The total number of reflections measured was 30120 , of which 7570 , were observed, $I>2 \sigma(I)$. Final indices: $R_{1}=0.0320$, $\mathrm{w} R_{2}=0.0837$. Crystallographic data for the structure of lycoposerramine $\mathrm{G}$ have been deposited in the Cambridge Crystallographic Data Centre (deposition number CCDC 1001520). Copies of the data can be obtained free of charge from the CCDC via www.ccdc.cam.ac.uk.

Acknowledgments This work was financially supported by the National Natural Science Foundation of China (Nos. 90813004 and U0932602) and the National Basic Research Program of China (973 Program No. 2011CB915503).

Conflict of Interest The authors declare no conflict of interest.

Open Access This article is distributed under the terms of the Creative Commons Attribution License which permits any use, distribution, and reproduction in any medium, provided the original author(s) and the source are credited.

\section{References}

1. N. Sizemore, S.D. Rychnovsky, Org. Lett. 16, 688-691 (2014)

2. L. Zhao, C. Tsukano, E. Kwon, Y. Takemoto, M. Hirama, Angew. Chem. 52, 1722-1725 (2013)

3. K. Bishayee, D. Chakraborty, S. Ghosh, N. Boujedaini, A.R. Khuda-Bukhsh, Eur. J. Pharm. 698, 110-121 (2013) 
4. L.B. Dong, X. Gao, F. Liu, J. He, X.D. Wu, Y. Li, Q.S. Zhao, Org. Lett. 15, 3570-3573 (2013)

5. M.G. Vallejo, M.G. Ortega, J.L. Cabrera, A.M. Agnese, Tetrahedron Lett. 54, 5197-5200 (2013)

6. Y. Hirasawa, J. Kobayashi, H. Morita, Heterocycles 77, 679-729 (2009)

7. X.Q. Ma, D.R. Gang, R. Nat. Prod. Rep. 21, 752-772 (2004)

8. W.A. Ayer, Nat. Prod. Rep. 8, 455-663 (1991)

9. X.J. Wang, L. Li, S.S. Yu, S.G. Ma, J. Qu, Y.B. Liu, Y. Li, Y. Wang, W. Tang, Fitoterapia 91, 74-81 (2013)

10. X.J. Wang, L. Li, Y.K. Si, S.S. Yu, S.G. Ma, X.Q. Bao, D. Zhang, J. Qu, Y.B. Liu, Y. Li, Tetrahedron 69, 6234-6240 (2013)

11. X.J. Wang, Y.B. Liu, L. Li, S.S. Yu, H.N. Lv, S.G. Ma, X.Q. Bao, D. Zhang, J. Qu, Y. Li, Org. Lett. 14, 5688-5691 (2012)

12. X.L. Li, Y. Zhao, X. Cheng, L. Tu, L.Y. Peng, G. Xu, Q.S. Zhao, Helv. Chim. Acta 89, 1467-1473 (2006)

13. J. Yan, L. Sun, X. Zhang, M. Qiu, Heterocycles 65, 661-666 (2005)

14. X. Cai, D. Pan, Y. Chen, W. Wu, X. Liu, Shanghai Yike Daxue Xuebao 18, 383-385 (1991)

15. J. He, X.Q. Chen, M.M. Li, Y. Zhao, G. Xu, X. Cheng, L.Y. Peng, M.J. Xie, Y.T. Zheng, Y.P. Wang, Q.S. Zhao, Org. Lett. 11, 1397-1400 (2009)
16. Y.R. Yang, L. Shen, K. Wei, Q.S. Zhao, J. Org. Chem. 75, 1317-1320 (2010)

17. T.T. Nakashima, P.P. Singer, L.M. Browne, W.A. Ayer, Can. J. Chem. 53, 1936-1942 (1975)

18. H. Takayama, K. Katakawa, M. Kitajima, K. Yamaguchi, N. Aimi, Chem. Pharm. Bull. 51, 1163-1169 (2003)

19. W.A. Ayer, B. Altenkirk, S. Valverde-Lopez, B. Douglas, R.F. Raffauf, J.A. Weisbach, Can. J. Chem. 46, 15-20 (1968)

20. D.B. MacLean, Can. J. Chem. 41, 2654-2670 (1963)

21. H. Morita, M. Arisaka, N. Yoshida, J.I. Kobayashi, J. Org. Chem. 65, 6241-6245 (2000)

22. B.D. Wang, J. Wang, H.F. Sun, D.Y. Zhu, Chin. J. Org. Chem. 21, 606-610 (2001)

23. C.H. Tan, D.Y. Zhu, Helv. Chim. Acta 87, 1963-1967 (2004)

24. X.D. Wu, J. He, G. Xu, L.Y. Peng, L.D. Song, Q.S. Zhao, Acta Bot. Yunnan. 31, 93-96 (2009)

25. Y.F. Yang, S.J. Qu, K. Xiao, S.H. Jiang, J.J. Tan, C.H. Tan, D.Y. Zhu, J. Asian Nat. Prod. Res. 12, 1005-1009 (2010)

26. B. Li, W.D. Zhang, Y.R. He, L. Lu, D.Y. Kong, Y.H. Shen, Chem. Pharm. Bull. 60, 1448-1452 (2012)

27. G.L. Ellman, K.D. Courtney, V.J. Andres, R.M. Featherstone, Biochem. Pharmacol. 7, 88-95 (1961) 